\title{
酸性電解水によるオイルの溶解作用
}

\author{
竹ノ内敏一*，吉池＼cjkstart潤*，若林 信一* \\ *新光電気工業(株)（†381-0014＼cjkstart長野県長野市北尾張部 36）
}

\section{Oil Dissolution Ability of Electrolyzed Acid Water}

\author{
Toshikazu TAKENOUCHI*, Jun YOSHIIKE* and Shin-ichi WAKABAYASHI* \\ *Shinko Electric Industry Co., Ltd. (36, Kitaowaribe, Nagano-shi, Nagano 381-0014)
}

\begin{abstract}
The effect of oil dissolution by electrolyzed acidic solution was confirmed. As a result of that, the electrolyzed acidic solution obtained by electrolysis with a dilute sodium chloride and sodium sulfate solution was found to dissolve oil remarkably well, but while an ordinary acidic solution which was arranged to have the same $\mathrm{pH}$ as the electrolyzed acidic water hardly dissolved oil at all. The oil dissolution was assumed to be caused by the high concentration of dissolved oxygen contained in the electrolyzed acidic water. The electrolyzed acidic water of the sodium chloride solution thus decomposes a part of the oil. It was aiso recognized to have other effects, such as hydrophilicity and to produces several kinds of volatile byproducts. Since the electrolyzed acidic water of sodium sulfate did not show this kind of phenomenon, the oil decomposition was suspected to be caused by hypochlorous acid occurring at anode electrode during the electrolysis of the sodium chloride solution.
\end{abstract}

Key Words : Electrolyzed Acidic Water, Oil Dissolution, Dissolution Mechanism, Hypochlorous Acid

\section{1. 緒言}

電解水とは，希薄な電解質水溶液を電解処理して得られる 水溶液の総称である。電極間を隔膜で隔て, 食塩などの電解 質を加えた水溶液を電気分解すると，陽極・陰極側それぞれ の槽に, 正・負の大きな酸化還元電位を持つ酸性電解水, ア ルカリ性電解水が得られる11。アルカリ性電解水は, その水 溶液がアルカリ性を示すために, 油脂やタンパク質に対して 乳化や分解作用を示し, 脱脂洗浄が可能であることから，こ れまで主に厨房での洗浄に用いられてきた。最近ではその洗 浄力が注目され, 機械, 金属分野の金属加工品のオイル洗浄 において，有機溶剤や界面活性剤などの薬液を使用せずに金 属加工部品の洗浄を行う安全な工業洗浄システムとして注目 されている。このアルカリ性電解水を用いて, プレス油に浸 漬した電子部品用の金属を洗浄し, その洗浄性を評価した結 果, アルカリ性電解水で洗浄したものは, 従来の化学薬品を 用いて洗浄する方法と同等の洗浄性が得られることがわかっ $た^{2)}$ 。さらにその後の研究で, 酸性電解水はアルカリ性電解 水よりも洗浄性に優れていることもわかった。酸性電解水の 優れた洗浄性は，酸化した金属皮膜を溶解する作用のほかに， 高い溶存酸素濃度によるオイルの溶解作用によるものと推測 した。特に, オイルの溶解作用は, 塩化ナトリウムによって 陽極室で生成する次亜塩素酸が関与しているのではないかと 推測した ${ }^{3)}$ 。

そこで本研究では, 酸性電解水がオイルを溶解する機構を 検証することを目的として以下の実験を行った。すなわち， 酸性電解水にオイルを加えて振とうし, 水溶液中に溶解した
オイルの溶解度と, 振とう前後におけるオイル量の減少量を 求めた。さらに, 次亜塩素酸によって, オイルの一部が分解 して新たな物質が生じる可能性が考えられるので, 副生成物 の定性分析を行った。な扔本稿では, 鉱物油を主成分とする 工作油・プレス油などを総称してオイルと呼ぶことにする。

\section{2. 実験方法}

\section{1 オイルの電解水に対する溶解度}

2. 1.1 使用薬品, 装置および器具

オイルはプレス油, 工作油を用いた。本実験では, オイル として工作油 (ユシロ化学工業, 粘度 $60.0 \mathrm{~mm}^{2} / \mathrm{s}\left(20^{\circ} \mathrm{C}\right.$ ), 複 数種のアルカン, 油脂, 塩素系添加剤, 防錆剂から成る) と プレス油 (日本工作油, 粘度 $20.0 \mathrm{~mm}^{2} / \mathrm{s}\left(20^{\circ} \mathrm{C}\right.$ ), 複数種のア ルカン, 油脂, 塩素系添加剤, 防錆剤から成る)を用いた。 鉱物油を主成分とする工作油・プレス油などを総称して本稿 ではオイルと呼ぶことにする。オイルの抽出溶剤は, クロロ フルオロカーボン $\mathrm{C}_{4} \mathrm{~F}_{6} \mathrm{Cl}_{4}$ （堀場製作所製 $\mathrm{S}-316$ )を用いた。 抽出溶剂中のオイル濃度は油分濃度計(堀場製作所 OCMA 350) を用いた。電解水とオイルの振とうと分離には 分液ロートを用いた。電解水を得るための電気分解の装置は 隔膜式電解装置 (MIZ (侏) JED-007) を用いた。同装置は陽極 槽(容積 $700 \mathrm{~mL}$ ) と陰極槽(容積 $700 \mathrm{~mL}$ ) から成り, 両者の間 は隔膜で仕切られている。電極にはチタンに白金皮膜を形成 したものが用いられ，両電極寸法は $74 \mathrm{~mm} \times 113 \mathrm{~mm}$ である。 電気分解の条件は，0.6 A, $100 \mathrm{~V}, 15$ 分とした。電解質は 塩化ナトリウム, 硫酸ナトリウムを用い, これらの $8.6 \mathrm{mM}$ 水溶液を電気分解して得られる酸性電解水を用いた。酸には 
Table 1 Solutions used in this study and its characteristics.

\begin{tabular}{l|c|c}
\hline \multicolumn{1}{c|}{ Solution } & $\mathrm{pH}$ & $\begin{array}{c}\text { Dissolved oxygen } \\
\mathrm{mg} / \mathrm{L}\end{array}$ \\
\hline Electrolyzed acid water of $8.6 \mathrm{mM} \mathrm{NaCl}$ solution & 2.6 & 9.2 \\
\hline Electrolyzed acid water of $8.6 \mathrm{mM} \mathrm{Na}_{2} \mathrm{SO}_{4}$ solution & 2.6 & 17.2 \\
\hline Diluted $\mathrm{HCl} \mathrm{solution}_{2} \mathrm{Na}_{2}$ solution & 2.6 & 7.8 \\
\hline Diluted $\mathrm{SO}_{4}$ & 2.6 & 7.8 \\
\hline De-ionized water & 5.8 & 7.8 \\
\hline
\end{tabular}

塩酸, 硫酸を用いた。溶存酸素の測定は溶存酸素計 (METTLER TOLEDO 製MO 128) を用いた。

\section{1.2 実験方法}

表 1 に示す $8.6 \mathrm{mM}$ 塩化ナトリウム酸性電解水, $8.6 \mathrm{mM}$ 硫酸ナトリウム酸性電解水, $\mathrm{pH} 2.6$ の希塩酸水溶液, 希硫 酸水溶液を試料水溶液とし, それぞれ $100 \mathrm{~mL}$ を $300 \mathrm{~mL}$ 分 液ロートに入れ, さらに工作油またはプレス油を $10 \mathrm{~mL}$ 入 れ，10 分間振とうした。一日静置して相分離させ，水相を 別の分液ロートに取り出し, これに抽出溶媒を $10 \mathrm{~mL}$ 加え, 10 分間振とうし, 抽出操作を行った。一日静置して相分離 させた後, 抽出溶剤を取り出し, 含まれるオイル量を, 油分 濃度計を用いて定量した。油分濃度計は, 赤外吸収法により 試料中の炭化水素を定量する装置である。鉱物油や油脂は, 分子中に C-H 結合を持ち, 波長 3400〜3500 nm (2941〜2857 $\left.\mathrm{cm}^{-1}\right)$ 付近には, この C-H 結合による吸収があるため, こ の吸収帯域における吸光度から試料中のオイル濃度を定量す る。

\section{2 油相中のオイルの定量分析}

2. 2. 1 使用薬品, 装置および器具

オイルは工作油を用いた。試料水溶液は表 1 に示すものを 用いた。試料水溶液とオイルの振とうと分離には分液ロート を用いた。オイルの定性・定量は GC/MS (Gas Chromatograph/Mass Spectrometry：ガスクロマトグラフ/質量分 析)装置(Agilent 製 6890 PLUS)を用いた。

\section{2. 2 実験方法}

表 1 に示す試料水溶液それぞれ $200 \mathrm{~mL}$ を分液ロートに入 れ，さらにそれぞれに工作油 $10 \mathrm{~mL}$ を加えて 10 分間振とう した。静置, 相分離させた後, 油相は $3000 \mathrm{rpm}, 30$ 分の遠 心分離処理行い, 水相・油相の分離を行った後, 油相はへキ サンで 1000 倍希釈し, GC/MS 分析を行い, 油相中のオイ ル量を定量した。GC/MS の測定条件を表 2 に示す。

\section{3 オイルの分解生成物の確認}

2. 3. 1 使用薬品, 装置扔よび器具

塩化ナトリウムの酸性電解水で生じる次亜塩素酸によって オイルの一部が分解する可能性が考えられるので, その検証 としてオイルと酸性電解水を加えて生じる副生成物の定性分 析を検討した。オイルは多成分のアルカンなどから成るため, 副生成物の定性が困難になるので, アルカンの代表例として トリデカン $\mathrm{C}_{13} \mathrm{H}_{28}$ (和光純薬，試薬特級)を試料として用い た。試料水溶液は表 1 のものを用いた。トリデカンを混ぜた 試料水溶液の振とうと分離には分液ロートを用いた。副生成 物の定性分析は GC/MS 装置を用いて行った。
Table 2 GC/MS conditions for oil analysis.

\begin{tabular}{l|l}
\hline $\mathrm{GC}$ & Agilent 6890 PLUS \\
\hline Column & $\begin{array}{l}\text { GL Sciences } \\
\text { TC-5 HT } 30 \mathrm{~m} \text { long, } 0.25 \mathrm{~mm} \text { i.d., } 0.25 \mu \mathrm{m} \text { df }\end{array}$ \\
\hline Column temp. & $60^{\circ} \mathrm{C}(1 \mathrm{~min})-.10^{\circ} \mathrm{C} / \mathrm{min} .-250^{\circ} \mathrm{C}(5 \mathrm{~min})$. \\
\hline Carrier gas & $\mathrm{He}$ \\
\hline Injection system & Splitless \\
\hline M S & $\mathrm{JEOL} \mathrm{Ltd.,} \mathrm{Automass} \mathrm{Sun}$ \\
\hline Interface temp. & $230^{\circ} \mathrm{C}$ \\
\hline Ionization method & $\mathrm{EI}(70 \mathrm{eV})$ \\
\hline Ion source temp. & $250^{\circ} \mathrm{C}$ \\
\hline Detection mode & $\mathrm{SCAN} \quad \mathrm{m} / \mathrm{z}=45 \sim 450$ \\
\hline
\end{tabular}

\section{3.2 実験方法}

分液ロートに純水 $1000 \mathrm{~mL}$, トリデカン $10 \mathrm{~mL}$ を加えて 10 分間振とうした後, 1 日間静置して相分離させ, トリデ カンの飽和水溶液を生成した。その後, トリデカン飽和水溶 液である水相から $100 \mathrm{~mL}$ 採取し, これに表 1 に示す試料溶 液 $100 \mathrm{~mL}$ を加え，10 分間振とうした。塩化ナトリウム酸性 電解水を混ぜたものは, トリデカンの分解生成物として低沸 点の揮発性物質を生成している可能性があるので, 各試料溶 液について, ヘッドスペース - GC/MS で分解生成物の定性 分析を行った。前処理方法として, 試料 $15 \mathrm{~mL}$ をバイアル 瓶に入れ, HS-GC/MS に導入し, $70^{\circ} \mathrm{Cで} 30$ 分間加熱し, バイアル瓶内気相の定性分析を行った。

\section{4 TOC の測定}

トリデカンの無機化を確認するためにTOC(Total Organic Carbon：全有機炭素)の定量を行った。まず分液 ロートに純水 $1000 \mathrm{~mL}$ ，トリデカン $10 \mathrm{~mL}$ を加えて 10 分間 振とうした後, 1 日静置して相分離させ, トリデカンの飽和 水溶液を生成した。このトリデカン飽和水溶液と, 表 1 の各 試料水溶液を同体積で混ぜ, TOC を測定した。TOCの測定 は JIS K 0102 (工場排水試験方法 22 項) に基づき, 全有機炭 素測定装置(島津製作所 TOC 5000 A) を用いて行った。

\section{3. 結果と考察}

\section{1 オイルの溶解度}

各試料水溶液に溶解するオイルの溶解度の測定結果を表 3 に示す。電解水の $\mathrm{pH}$ と同じに調製した塩酸水溶液, 硫酸水 溶液にはオイルはほとんど溶解しなかったのに対し，2 種類 の酸性電解水は, ともに大きな溶解度を示した。これら酸性 水溶液の溶存酸素は, 表 1 に示すようにともに高い值を示し ている。そこで, 溶存酸素の影響を確認するために溶存酸素 
Table 3 Solubility of oils in each solutions.

\begin{tabular}{l|c|c}
\hline \multirow{2}{*}{ Solution } & \multicolumn{2}{c}{ Solubility, mg oil/100 g solution } \\
\cline { 2 - 3 } & Machining oil & Press oil \\
\hline $\mathrm{NaCl}$ electrolyzed acid water, pH 2.6 & 7.19 & 3.90 \\
\hline $\mathrm{H}_{2} \mathrm{SO}_{4}$ electrolyzed acid water, pH 2.6 & 8.18 & 4.30 \\
\hline Diluted $\mathrm{HCl}$ solution, pH 2.6 & 0.01 & 0.01 \\
\hline Diluted $\mathrm{H}_{2} \mathrm{SO}_{4}$ solution, pH 2.6 & 0.01 & 0.01 \\
\hline Deionized water & 1.65 & 0.74 \\
\hline
\end{tabular}

Table 4 Effect of dissolved oxygen on oil solubility.

\begin{tabular}{c|c}
\hline Characteristics of electrolyzed acid water & $\begin{array}{c}\text { Solubility of oil } \\
\text { mg oil/100 g solution }\end{array}$ \\
\hline $\begin{array}{c}\text { Electrolyzed acid water of } 8.6 \mathrm{mM} \mathrm{NaCl} \\
\mathrm{pH} 2.6, \text { dissolved oxygen } 9.2 \mathrm{mg} / \mathrm{L}\end{array}$ & 7.19 \\
\hline $\begin{array}{c}\text { Electrolyzed acid water of } 0.17 \mathrm{mM} \mathrm{NaCl} \\
\mathrm{pH} 2.7, \text { dissolved oxygen } 20 \mathrm{mg} / \mathrm{L}\end{array}$ & 12.82 \\
\hline
\end{tabular}

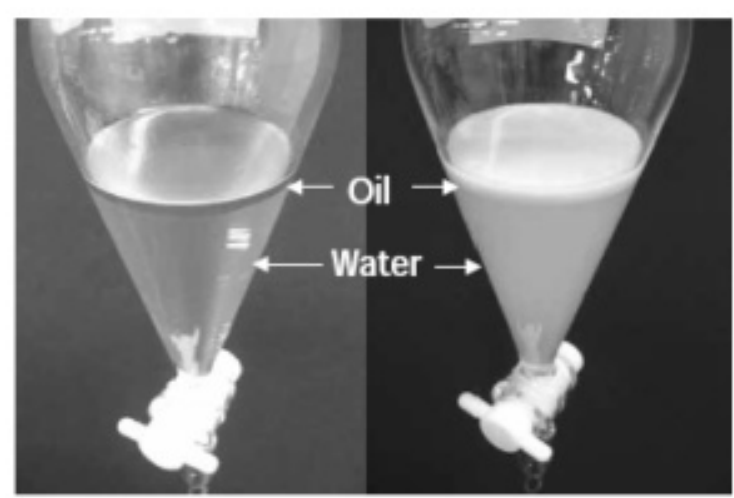

Fig. 1 Appearance of solution mixed and shook with oil. Left : electrolyzed acid water with oil, Right : electrolyzed alkaline water with oil

濃度をさらに高めた塩化ナトリウム酸性電解水を調製し, こ れに溶解するオイル量を調べた。溶存酸素濃度を高めるため に塩化ナトリウム濃度を $0.17 \mathrm{mM}$ に下げて電気分解を行っ た。塩化ナトリウム水溶液の電解では, 酸素よりも塩素発生 の過電圧のほうが低いために塩素発生が優位となる。しかし, 塩化ナトリウムの濃度を下げて電解を行うことによって塩素 発生を抑え, 溶存酸素濃度を高めることが可能である。溶存 酸素濃度は $8.6 \mathrm{mM}$ 塩化ナトリウム水溶液の酸性電解水が $9.2 \mathrm{mg} / \mathrm{L}$ であるのに対し, $0.17 \mathrm{mM}$ 塩化ナトリウム水溶液

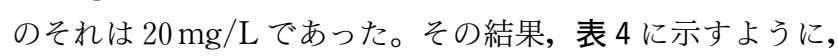
溶存酸素が高いほうが明らかに高いオイル溶解度を示した。 この現象は, 高濃度に溶解した酸素が, 被洗浄物とオイルの 隙間に入り込み，オイル滴の表面全体を包み込むようにして 付着した結果，オイルが被洗浄物から引き剥がされるのでは ないかと推測する。ガス溶解水がシリコンウェ八表面を研磨 した後の微粒子を除去するのに効果的であることが知られて いるように ${ }^{4)}$, 酸素溶解水も同様にオイル微粒子を除去する 作用があると考える。現時点では, 溶存酸素濃度だけでは, オイルの溶解現象を説明できないが, 酸性電解水の電気泳動 やゼー夕電位を測定することで新たな知見が得られるものと 考えており, 今後の課題である。なお, 図 1 に酸性電解水,

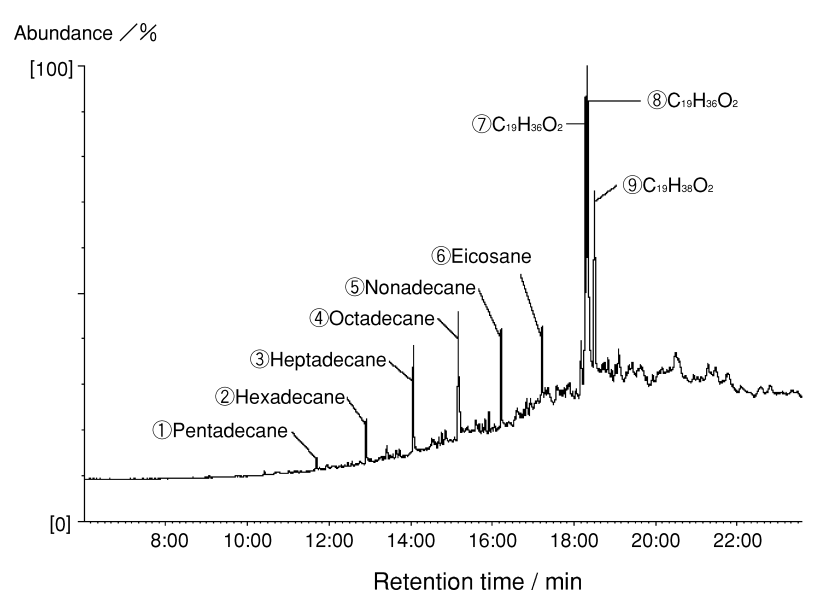

Fig. 2 Total ion chromatograph of Oil.

Table 5 Quantitative analysis of oil in organic phase extracted in hexane by GC/MS.

\begin{tabular}{|c|c|}
\hline Extractant solution & $\begin{array}{l}\text { Quantity of oil in oil phase* } \\
\text { (Relative ratio, \%) }\end{array}$ \\
\hline $\mathrm{NaCl}$ electrolyzed acid water & 97.4 \\
\hline $\mathrm{H}_{2} \mathrm{SO}_{4}$ electrolyzed acid water & 99.6 \\
\hline Diluted $\mathrm{HCl}$ solution & 99.9 \\
\hline Deionized water & 99.9 \\
\hline
\end{tabular}

アルカリ性電解水とオイルを振とうした後の外観を示す。酸 性電解水の場合，オイルは分液ロート内壁には付着せず，し かも油相と水相は短時間できれいに相分離するが，アルカリ 性電解水の場合, その乳化作用のためエマルジョン状になり, 分液ロート内壁に付着して相分離に時間がかかる。また, 塩 化ナトリウム, 硫酸ナトリウムいずれの酸性電解水とオイル を混ぜて振とうしても外観には差がなかった。

\section{2 油相中のオイルの定量分析}

工作油のトータルイオンクロマトグラムを図 2 に示す。工 作油は, 複数種のアルカン (図中の(1)〜 (6) ) と，カルボン酸メ チル化合物 (7)～(9) から成ることがわかる。トータルイオン クロマトグラムにおけるカルボン酸メチル化合物およびアル カンのピーク強度を $100 \%$ として, 油相中に含まれるオイル の相対量を定量した。結果を表 5 に示す。塩化ナトリウムの 酸性電解水にオイルを加えて振とうした場合, 油相中に残存 するオイル量は, 純水や $\mathrm{pH} 2.6$ の塩酸水溶液よりも $2.5 \%$ (オイルの体積換算で $0.25 \mathrm{~mL}$ ) 減少していることがわかる。 また, 硫酸ナトリウムの酸性電解水は純水, 硫酸水溶液より も $0.3 \%$ (オイルの体積換算で $0.03 \mathrm{~mL}$ ) 減少した。体積減少 
分が水溶液への溶解と考えられるが, 塩化ナトリウムの酸性 電解水の場合, 生じる次亜塩素酸によってオイルの成分の一 部が分解し, 副生成物を生成している可能性も考えられる。

\section{3 トリデカンの分解生成物の確認}

体積減少したものが何に変化したのか調べるために，オイ ルの代表例としてトリデカンを用い, この分解生成物の定性 を行った。実験に先立ち, 3.2 .2 の実験方法に準じてトリデ カン $10 \mathrm{~mL}$ と, 塩化ナトリウムの酸性電解水, $\mathrm{pH} 2.6$ の塩 酸水溶液, 純水それぞれ $200 \mathrm{~mL}$ を混ぜて振とうし, 水相を ヘキサンで抽出し, 抽出液のトータルイオンクロマトグラム を求めた。結果を図 3 に示す。この結果から, 表 3 と同様に, トリデカンは酸性電解水に溶解するが, $\mathrm{pH}$ を同じに調整し た塩酸水溶液にはほとんど溶解しないことがわかった。トリ デカンが塩化ナトリウムの酸性電解水に溶解することを確認 したので，ヘッドスペース-GC/MS で分解生成物の定性分 析を行った。その結果, 図4 に示すように, トータルイオン クロマトグラムからは, はっきりとしたピークが表れず同定 ができなかった。そこで，ギ酸，酢酸，クロロホルム，ベン ゼン, クロロベンゼンについて, それぞれシングルイオンモ ニタリングを行った。モニターイオン質量 $(\mathrm{m} / \mathrm{z})$ はそれぞれ 46，60，83，78，112である。代表例として，ギ酸のシング ルイオンモニタリングの結果を図 5 に示す。塩化ナトリウム の酸性電解水を用いた場合だけにギ酸が検出されている。同 様に, 酢酸, クロロホルム, ベンゼン, クロロベンゼンも塩 化ナトリウムの酸性電解水を用いた場合だけに検出された。 以上の結果から, 塩化ナトリウムの酸性電解水によって, ト リデカンはその一部が分解し, 微量ながら, 親水性のギ酸, 酢酸と, 揮発性のクロロホルム, ベンゼン, クロロベンゼン など新たな物質を生成することがわかった。すなわち，オイ ルの一部は分解し, 水溶性の物質と揮発性の物質に変化した ものと推測する。

ところで, フェノール化合物は, 塩素処理によって複数の 塩素化フェノール化合物を副生成物として生成し, しかも, 反応処理時間や有効塩素濃度などによって副生成物の内容と

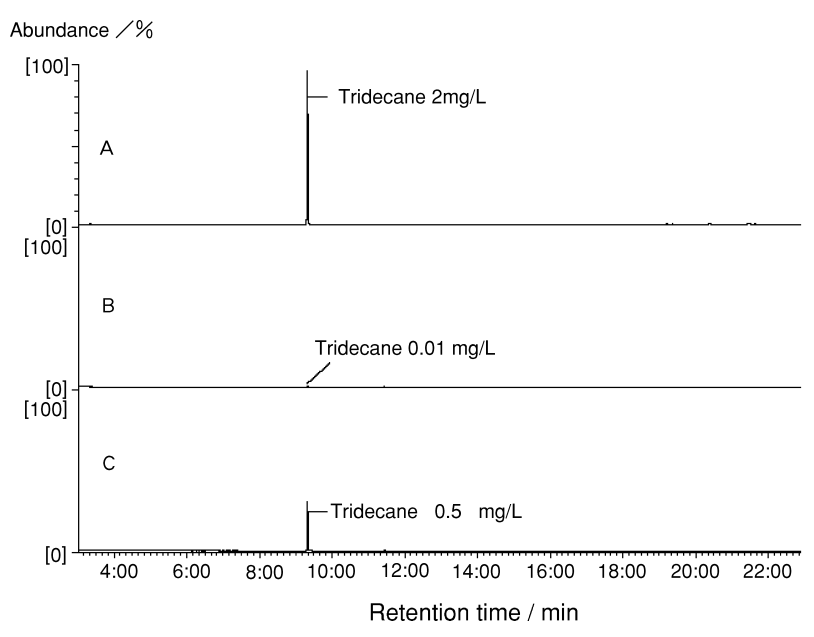

Fig. 3 Total ion chromatographs of hexane extrant, each solutions are mixed and shook with tridecane.

Solutions are $\mathrm{A}: \mathrm{NaCl}$ electrolyzed acidic solution, $\mathrm{B}: \mathrm{HCl}$ solution $\mathrm{pH} 2.6, \mathrm{C}$ : distilled pure water.
量が変化することが知られている5)。次亜塩素酸による有機 物の分解は, 塩素処理であることから, 本実験で生じたクロ ロホルムやクロロベンゼンなどの有機塩素化合物は, 次亜塩 素酸による塩素化反応によって生じたものと考える。

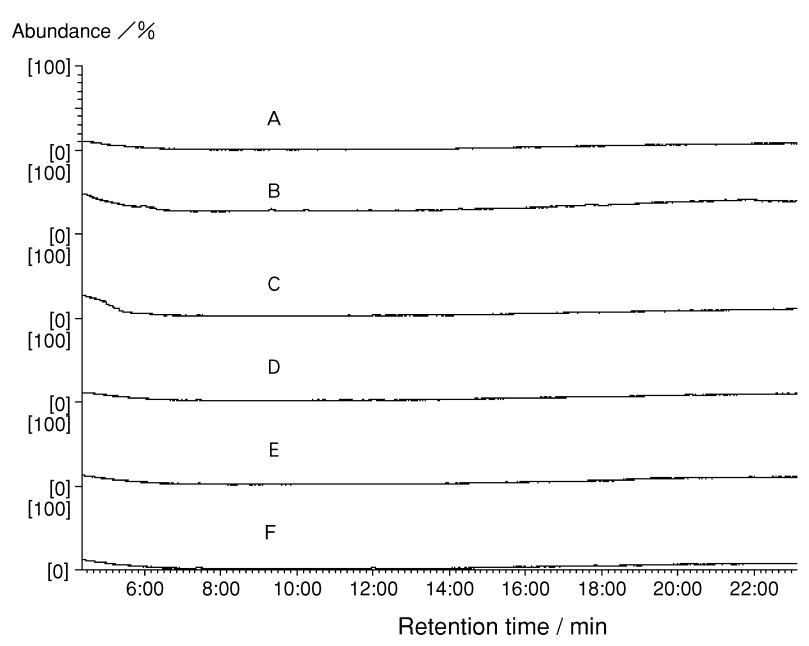

Fig. 4 Total ion chromatographs of head space-GC/MS analysis.

A : Distilled pure water, B:Distilled pure water saturated with tridecane are mixed with $\mathrm{NaCl}$ electrolyzed acidic solution, $\mathrm{C}$ : Distilled pure water saturated with tridecane are mixed with $\mathrm{Na}_{2} \mathrm{SO}_{4}$ electrolyzed acidic solution, D : Distilled pure water saturated with tridecane are mixed with $\mathrm{HCl}$ solution $\mathrm{pH} 2.6$, E; Distilled pure water saturated with tridecane are mixed with $\mathrm{H}_{2} \mathrm{SO}_{4}$ solution $\mathrm{pH}$ 2.6, F : Distilled pure water saturated with tridecane.

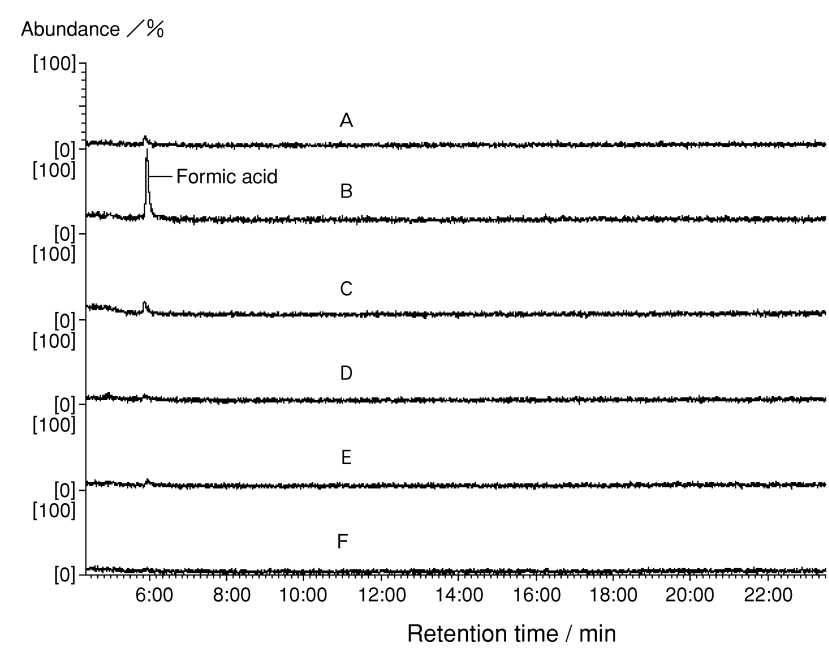

Fig. 5 Single ion monitoring of head space-GC/MS analysis, $\mathrm{m} / \mathrm{z}=46$ formic acid.

A : Distilled pure water, B : Distilled pure water saturated with tridecane are mixed with $\mathrm{NaCl}$ electrolyzed acidic solution, $\mathrm{C}$ : Distilled pure water saturated with tridecane are mixed with $\mathrm{Na}_{2} \mathrm{SO}_{4}$ electrolyzed acidic solution, D : Distilled pure water saturated with tridecane are mixed with $\mathrm{HCl}$ solution pH 2.6, E; Distilled pure water saturated with tridecane are mixed with $\mathrm{H}_{2} \mathrm{SO}_{4}$ solution $\mathrm{pH}$ 2.6, F : Distilled pure water saturated with tridecane. 
なお本実験では, 分解前後における物質収支を求めていな いが, 定量分析については今後の課題である。また, 次覀塩 素酸によるオイル成分の分解がオイルの溶解性にどの程度寄 与しているか, 現時点では不明だが, この解明も今後の課題 である。

\section{4 TOC}

トリデカン飽和水溶液と表 1 に示す各試料水溶液を同体積 で混ぜた水溶液の TOC を測定した結果, いずれの混合水溶 液も TOCの低減がなかったことから，オイルは無機化され なかったことがわかる。先に著者らは, 酸性電解水による金 属表面の脱脂洗浄作用は, 電解で生じた次亜塩素酸やヒドロ キシルラジカルによって, 金属表面に残留したオイルの一部 が酸化分解され，二酸化炭素になって除去されるのではない かと推測したが ${ }^{3)}$, 無機化ではなく, 新たな分解副生成物に 変化したと考える。

\section{4.まとめ}

酸性電解水によるオイルの溶解作用を検証した。その結果, 酸性電解水と $\mathrm{pH}$ を同じに調整した酸の水溶液にはほとんど 溶解しないのに対し, 塩化ナトリウム, 硫酸ナトリウム水溶 液を電気分解して得られる酸性電解水では, 著しくオイルを 溶解することがわかった。酸性電解水には, 高濃度の溶存酸
素が存在しており, これがオイルの溶解性を高めている一因 と推測する。また, 塩化ナトリウムの酸性電解水は, オイル の一部を分解し, 親水性, 揮発性の複数の分解副生成物を生 じる作用があることがわかった。硫酸ナトリウムの酸性電解 水ではこの現象は見られなかったことから, 分解作用は, 塩 化ナトリウムの電気分解時に陽極室で生じる次亜塩素酸によ る酸化分解と考えられる。

\section{謝辞}

本研究の遂行にあたり，オイルの提供とアドバイスを頂き ました信州大学教育学部助教授佐藤雲海氏, GC/MS 分析に 協力頂きました侏富士電化環境センター大脇卓敏氏, 早瀬祥 平氏の諸氏に深謝いたします。

(Received June 7,2004; Accepted August 20,2004)

\section{文献}

1 ) 電解水ガイド, 財機能水研究振興財団 (2001)

2 ) 竹ノ内敏一, 田中博志, 若林信一 ; 表面技術, 54, 818 (2003)

3 ) 竹ノ内敏一, 吉池 潤, 若林信一 ; 表面技術, 55, 208 (2004)

4 ）今岡孝之, 山中弘次；表面技術, 51, 141 (2000)

5 ) J. Hu, T. Aizawa, and S. Ookubo ; Environ. Sci. Technol., 36, 1980 (2002) 